\title{
Graphomya Robineau-Desvoidy from Costa Rica: descriptions and first records (Diptera, Muscidae)
}

\author{
Couri, MS.* and Marques, $B{ }^{\mathrm{a}}$ \\ Museu Nacional, Universidade Federal do Rio de Janeiro - UFRJ, \\ Quinta da Boa Vista, CEP 20940-040, Rio de Janeiro, RJ, Brazil \\ *e-mail: mcouri@terra.com.br \\ Received February 27, 2008 - Accepted June 11, 2008 - Distributed May 31, 2009 \\ (With 14 figures)
}

\begin{abstract}
Graphomya Robineau-Desvoidy (Diptera, Muscidae) occurs in temperate and tropical regions of the world. It is known in the Neotropical Region from fifteen species. The genus is here recorded for the first time from Costa Rica, on the basis of three species: G. auriceps Malloch, 1934; G. mexicana Giglio-Tos, 1893 and G. tropicalis Malloch, 1934. A key for the recognition of these three species is given. G. auriceps is redescribed, including the morphology of male and female terminalia and the male of $G$. tropicalis is described for the first time. For G. mexicana, a well-known species in the literature, only a brief diagnosis and the material examined are listed.
\end{abstract}

Keywords: morphology, Neotropical, terminalia, taxonomy, new records.

\section{Graphomya Robineau-Desvoidy da Costa Rica: descrições e primeiros registros (Diptera, Muscidae)}

\begin{abstract}
Resumo
Graphomya Robineau-Desvoidy (Diptera, Muscidae) ocorre em regiões temperadas e tropicais do mundo. É conhecido na Região Neotropical por quinze espécies. O gênero é aqui registrado, pela primeira vez, para a Costa Rica, através da presença de três espécies: G. auriceps Malloch, 1934; G. mexicana Giglio-Tos, 1893 e G. tropicalis Malloch, 1934. É fornecida uma chave para a segregação destas três espécies. G. auriceps é redescrita, incluindo a morfologia da terminália do macho e da fêmea e o macho de G. tropicalis é descrito pela primeira vez. Para G. mexicana, uma espécie bem conhecida na literatura, uma breve diagnose e a lista do material examinado são listados.
\end{abstract}

Palavras-chave: morfologia, neotropical, terminália, taxonomia, novos registros.

\section{Introduction}

Graphomya Robineau-Desvoidy is a well distributed genus, occurring in temperate and tropical regions of the world, being absent in New Zeland and Oceania (except in Micronesia and Hawaii). It is known in the Neotropical Region from fifteen species Carvalho et al., 2005; Couri and Marques, 2005; Marques and Couri, 2007).

Adults can be easily distinguished by the characteristic marks on mesonotum and abdomen (Couri and Carvalho, 2002: 166, figs 33 and 34; Marques and Couri, 2007:438, figures 1-21); holoptic males; arista with long plumae; dorsocentral setae 2:4; katepisternals $1: 1$ and sternite 1 setulose.

The genus has been recorded, in the Neotropical Region, in Mexico, Cuba, Puerto Rico, Brazil, Chile, Venezuela, Uruguay and Argentina.
The aim of this paper is to record the presence of Graphomya in Costa Rica for the first time, on the basis of three species. A key for the recognition of these three species is given.

\section{Material and Methods}

The material herein studied was collected by the "Plan de siete años para um inventario de los dípteros de Costa Rica", an inventory of the Diptera of Costa Rica. The project is under the international coordination of Dr. Manuel A. Zumbado (Instituto Nacional de Biodiversidad, INBC, Costa Rica) and the material was kindly loaned by him.

The terminalia were macerated in a solution of $10 \%$ potassium hydroxide, and then boiled in a water-bath 
for ten minutes. They were then dissected in glycerol, drawn, stored in a microtube with glycerol, and attached to the pin bearing the specimen. The terminology followed McAlpine (1981).

Some of the material examined was donated to the Museu Nacional, Universidade Federal do Rio de Janeiro (MNRJ) collection, as indicated in the text.

The material was quantitatively representative and some intraspecific variations could be observed.

Abbreviations of the institutions: MIZT (Università di Torino, Instituto e Museo di Zoologia, Torino, Italy); USNM (National Museum of Natural History, Washington, EUA); ZMUH (Zoologisches Institut und Zoologisches Museum, Hamburg, Germany).

\section{Results and Discussion}

Three species of Graphomya are here recorded from Costa Rica: G. auriceps Malloch, 1934; G. mexicana Giglio-Tos, 1893 and G. tropicalis Malloch, 1934. G. auriceps is Redescribed, including the morphology of male and female terminalia and the male of $G$. tropicalis is described for the first time. For G. mexicana, a wellknown species in the literature, only a brief diagnosis and the material examined are listed

All three species can be easily distinguished by the characteristic colour pattern of the mesonotum and abdomen.

\subsection{Key to the Costa Rican species of Graphomya}

1. Fronto-orbital plate and gena dark golden polinose; mesonotum brown with grey pollinose stripes, forming a characteristic pattern as in Figure 1 [Costa Rica, Argentina] ....

G. auriceps Malloch Fronto-orbital plate and gena silver polinose; mesonotum color pattern not as in Figure 1

...2

2. Mesonotum with 5 silver pollinose stripes presuturally [Mexico, Panama, Costa Rica, Bolivia, Argentina] .......................... G. mexicana Giglio-Tos Mesonotum with 2 silver pollinose stripes presuturally [Peru] G. tropicalis Malloch

\subsection{Graphomya auriceps Malloch, 1934 (Figures 1-9)}

Graphomya auriceps Malloch, 1934:346. Holotype female, ZMUH. Type-locality: Argentina, Província Mendoza.

Diagnosis: face, fronto-orbital plate and antenna dark brown with few golden pollinosity; mesonotum brown with grey pollinose stripes, forming a characteristic pattern as in Figure 1; scutellum dark brown in a triangular median area and laterally, two grey pollinose stripes between them; abdomen dark brown with silver pollinose areas laterally on each tergite.

Coloration: Arista, palpus and occiput dark brown. Mesonotum and abdomen as in diagnosis. Both calypter dark brown, the inferior darker. Wing faintly brownish; halter yellow. Legs dark brown, claws black and pulvilli yellow.

Male: Length: body: 8.2-10.0 mm; wing: 8.1-9.8 mm Head: Eyes ciliated. Frontal row with 9-11 pairs of bristles. Cephalic setae ciliform. Thorax: 2 postpronotals; 1 presutural; 2 post-alar; 2 intra-alars; 2 supra-alars; 1 intra-post-alar. Scutellum with a short pair of basal setae, one median sub-basal, one median pre-apical, one short discal and a long apical. Anepisternum with a row of 13-15 setae. Fore tibia on dorsal surface with a preapical seta and posterior surface with an apical. Mid femur with a row of sparse setae on basal half. Mid tibia with one apical setae on posterior, anterior and ventral surfaces. Hind tibia with a median anteroventral and anterodorsal short and one apical anteroventral seta. Abdomen: sternite 5 more or less as high as wide; anterior incision medium; setae on basal two thirds (Figure 2). Terminalia: cercal plate with a deep posterior incision; surstili long with round apex (Figures 3 and 4); phallic complex as in Figures 5 and 6.

Female: Length: body: 7.7-10.0 mm; wing: 9.0-10.0 mm. Similar to male, differing as follows: interocular space about one third of head width. Frons and gena with golden pollinosity stronger than in male. Frons with a straight median golden polinose stripe. Frontal row with 7 pairs of setae; one pair of orbital seta; 1 pair of post-ocelar fine and divergent; inner vertical seta strong and convergent, outer vertical seta strong and divergent. Ovipositor: with microtrichias; tergites large; sternites 7 and 8 with spines (Figure 7). Three round spermathecae (Figure 8). Egg as in Figure 9.

Material examined: Costa Rica: Prov. Puntarenas, P. N. La Amistad. Estácion Altamira, Cerro Biolley. 1,766 m. "L-S-332400-5722 00 \#63284. Graphomya R-D. C. J. B. Carvalho det. 2003/ J. Savage det. 2003”. 09-26.vii.2001. O. Alemãn. Manual., 1 female (INBC); Prov. Puntarenas, R. Coton, 1750 m. Las Tablas, Coto Brus. "L-S-322000-601000. Graphomya C. J. B. Carvalho det. 2003". 17.iii.1992. M. A. Zumbado, 2 males (MNRJ, INBC); Prov Limón, P. N. La Amistad. Bratsi, Cerrito en Fila Dudu-Apri. 3,110 m. "L-S-356400-566000 \#63236". 23.vii.2000. M. Alfaro Libre., 1 female (MNRJ).

Comments: The species was previously known only from Argentina.

\subsection{Graphomya mexicana Giglio-Tos, 1893}

Graphomya mexicana Giglio-Tos, 1893:5. Syntypes male and female, MIZT. Type-locality: Mexico, Tuxpango.

Diagnosis: face, fronto-orbital plate, parafacial and gena brown with grey pollinosity; mesonotum with 5 grey pollinose stripes presuturally, on acrostichal and dorsocentral surfaces of setae and laterally; scutellum dark brown on a central triangular area and grey pollinose laterally. Abdomen with tergites $1+2$ and 3 yellowish and tergites 4 and 5 brownish; all tergites with grey polinose areas and with a median brown stripe. 


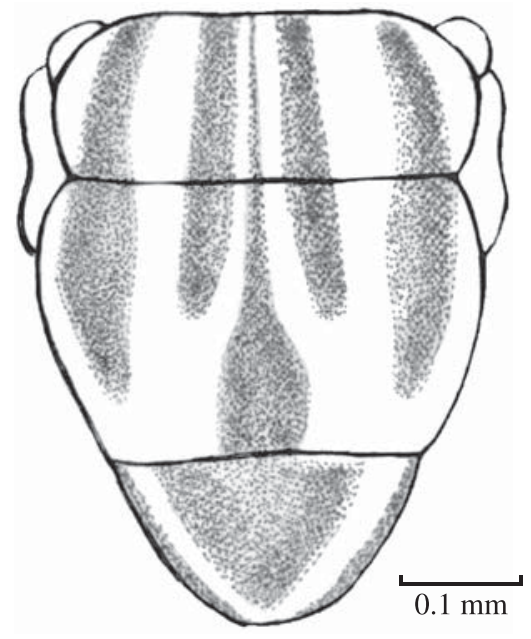

Figure 1. Graphomya auriceps Malloch - Mesonotum, male, dorsal view.

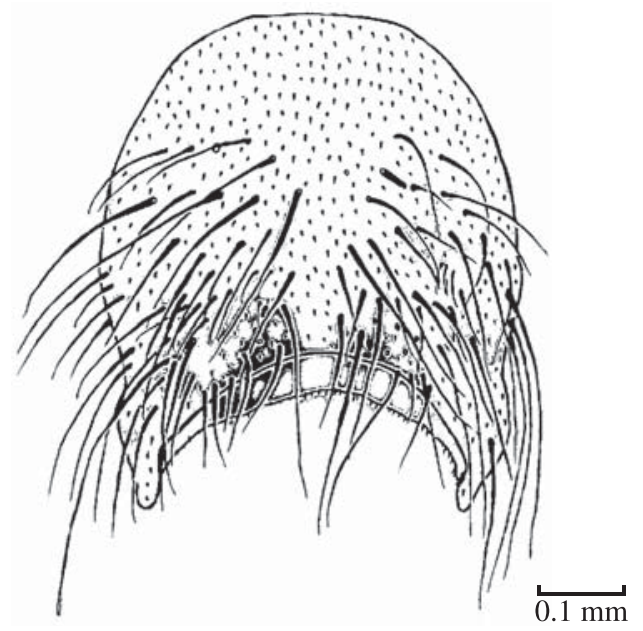

Figure 2. Graphomya auriceps Malloch - Sternite 5, dorsal view.

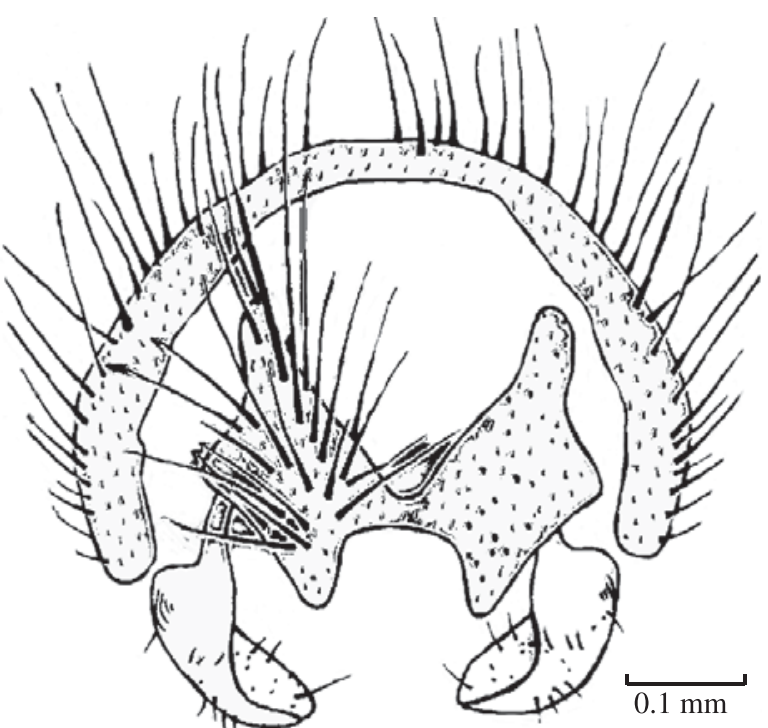

Figure 3. Graphomya auriceps Malloch - Epandrium, cercal plate and surstili, dorsal view.

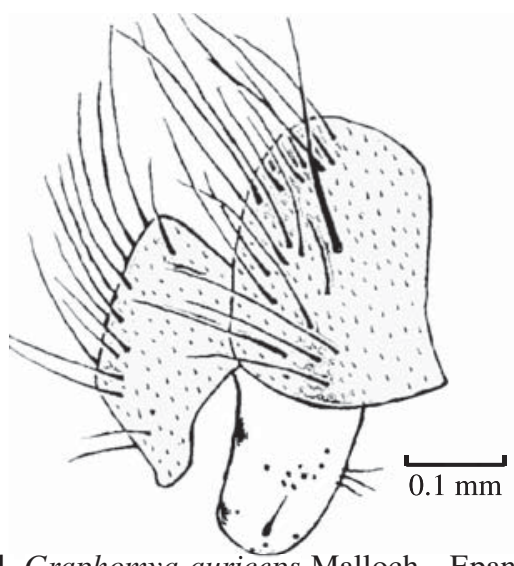

Figure 4. Graphomya auriceps Malloch - Epandrium, cercal plate and surstili, lateral view.

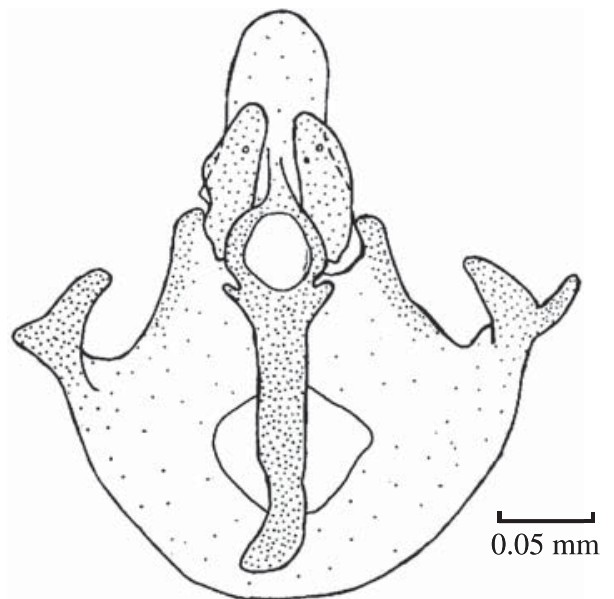

Figure 5. Graphomya auriceps Malloch - Phallic complex, dorsal view.

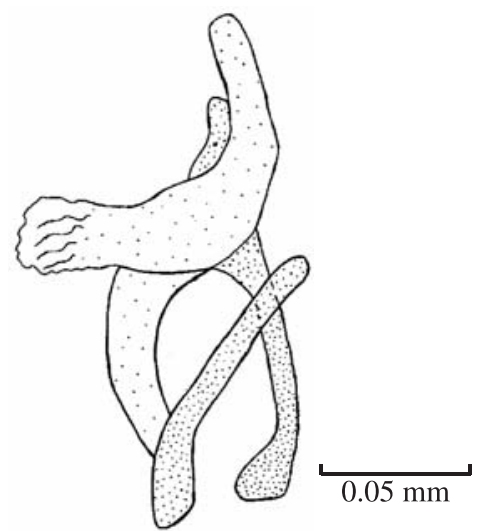

Figure 6. Graphomya auriceps Malloch - Phallic complex, lateral view.

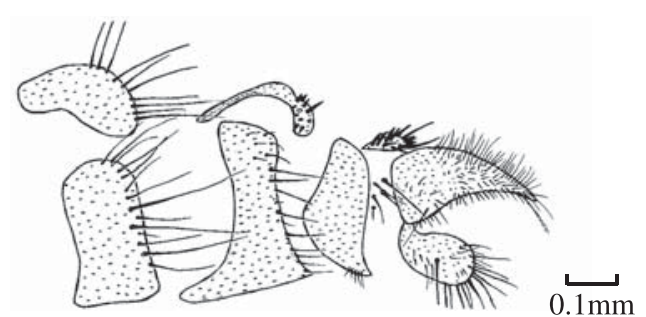

Figure 7. Graphomya auriceps Malloch - Ovipositor, lateral view. 
Material examined: COSTA RICA: Prov. Guanacaste: Libéria. Fca Jenny, 300 m, 31 km N. ix.88 GNP Biodiversity Survey W85 34' 27", N10 51' 55", 1 male (INBC); Liberia. Pque. Nal. Sta. Rosa, Stor Santa Rosa, Área Adm. 300 m. x.99 Janzen. Malaise L N 313000_359800 \#56050, 1 male (INBC); P. N. Palo Verde, Laguna Palo Verde. Frente O.E.T. 5-10 m. 17.viii.02. B. Hernandez, Libre LN 25900388400 \#71567, 5 males (INBC); P. N. Palo Verde. Frente a Estácion Palo Verde. 5-10 m. 22.viii.02

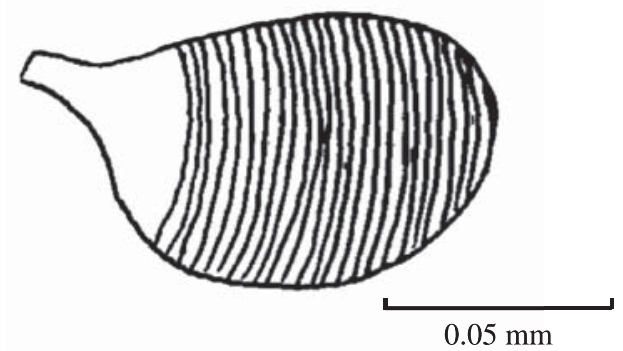

Figure 8. Graphomya auriceps Malloch - Spermatheca.

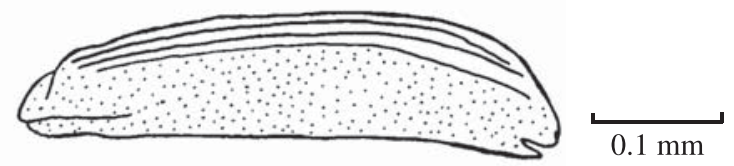

Figure 9. Graphomya auriceps Malloch - Egg, lateral view.

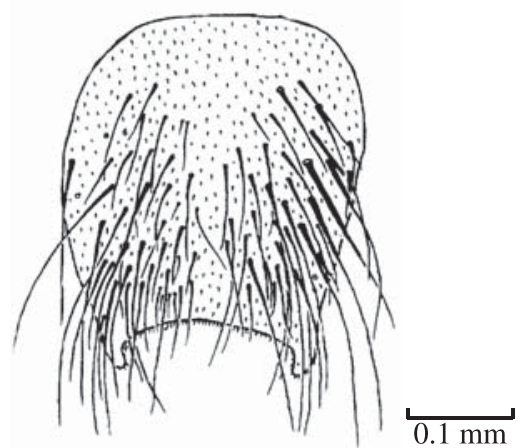

Figure 10. Graphomya tropicalis Malloch - Sternite 5, dorsal view.

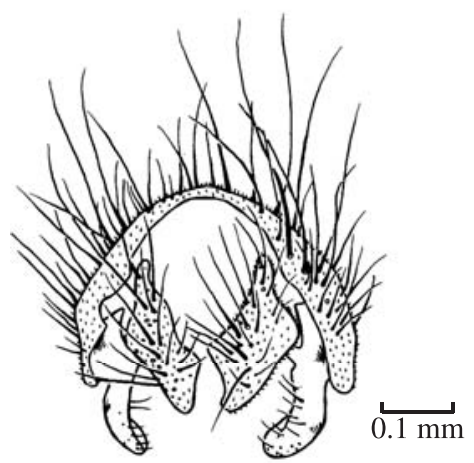

Figure 11. Graphomya tropicalis Malloch - Epandrium, cercal plate and surstili, dorsal view.
B. Hernandez Libre LN 259000388400 \#71572, 3 males (INBC); same locality, 10 m. 4-7.v.92. U. Chavarría. L-N-259000, 388400, 1 male (INBC); same locality, 10 m. 25.iii-21.iv.92. U. Chavarría. L-N-259000, 388400, 1 male (INBC); same locality, 10 m. 6-16.iii.93.

U. Chavarría. L-N-259000, 388400, 48 males (INBC); P. N. Guanacaste, Los Almendros. 24.viii-14.ix.92. E. Lopez. L-N-334800, 369800, 21 males (INBC); same locality, 1-22.vii.92. E. Lopez. L-N-334800, 369800, 1 male (INBC); same locality, 0 m. 21.xi-12.xii.92.

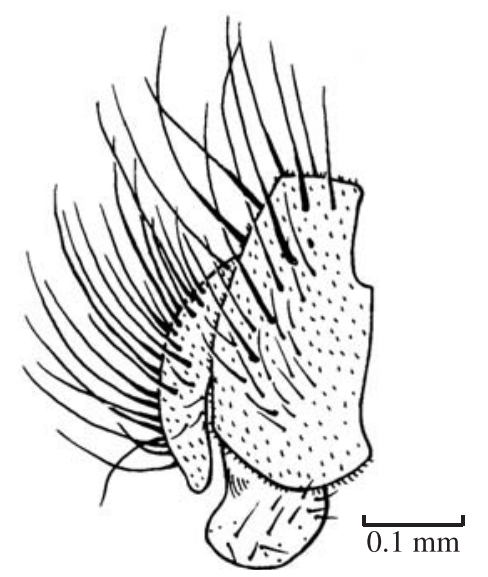

Figure 12. Graphomya tropicalis Malloch - Epandrium, cercal plate and surstili, lateral view.

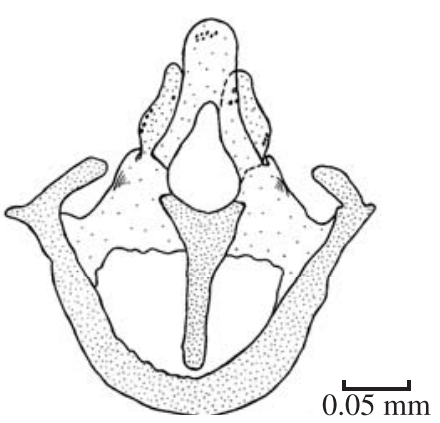

Figure 13. Graphomya tropicalis Malloch - Phallic complex, dorsal view.

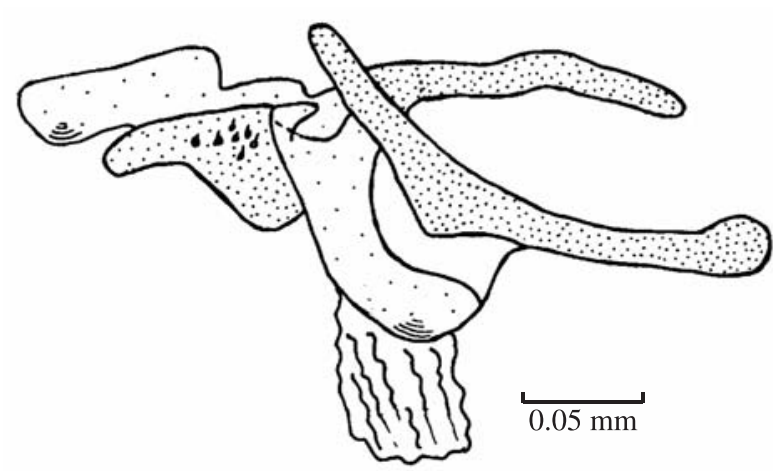

Figure 14. Graphomya tropicalis Malloch - Phallic complex, lateral view. 
E. Lopez. L-N-334800, 369800, 1 male (INBC); Ref. Nac. Fauna Silvestre Rafael Lucas Rodriguez, Palo Verde, 10 m. iii.91 U. Chavarría. L-N 259000, 388400, 43 males (INBC); same locality, 10 m. iii.91 D. Acevedo. L-N 259000, 388400, 23 males (INBC); Prov. Limon, Barra del Colorado, Rio Sardinas, 10 m. R. N. F. S. 2.vii.92. F. Araya. L-N 291500, 564700, 1 male (INBC); Prov. Alajuela, Caño Negro, R. N. V. S. 20-20 m. 14.vii-2.viii.93. K. F. Flores, LN 450100_319100 \#2285, 34 males (INBC); Puntarenas, Estacion Sirena. 1-10 m. iii.96 G. Fonseca. LS 270500-508300 \#7243, 5 males (INBC).

Comments: The species was previously known from Mexico, Panama, Bolivia and Argentina. Full description in Marques and Couri (2007).

\subsection{Graphomya tropicalis Malloch, 1934}

(Figures 10 and 14)

Graphomya tropicalis Malloch, 1934:345. Holotype female, USNM. Type-locality: Peru, Rio Huascarai.

Diagnosis: frons blackish; mesonotum dark brown with two straight silver pollinose stripes on dorsocentral surface; scutellum dark brown, silver pollinose on lateral margins; abdomen dark brownish with adjacent grey pollinose areas and also laterally; tergites 1+2-4 with yellow large areas, more intense than in female; tergite 5 with 3 dark brown median stripes, converging from margin to apex.

Male: Length: body: $7.4 \mathrm{~mm}-9.1 \mathrm{~mm}$; wing: $7.0 \mathrm{~mm}-9.0 \mathrm{~mm}$. Head: interocular space about 0.09- 0.1 of head width. Frontal row with 8-9 pairs of setae. Cephallic setae ciliformes. Thorax: 2 post-pronotal setae; 1 post-umeral; 2 post-alars; 2 intra-alars; 2 supra-alars; 1 intra-post-alar. Scutellum with 1 short basal pair of setae, 1 pair sub-basal, 1 pre-apical and 1 apical longer than the others. Fore tibia with a dorsal pré-apical seta; posteroventral surface with an apical seta. Mid tibia with a median posteroventral seta; 1 supramedian and 1 submedian posterior setae; 1 pre-apical dorsal; posteroventral, anterior and ventral surfaces with one apical seta. Hind femur with a row of sparse and fine posteroventral setae on basal half. Hind tibia with an apical anteroventral seta. Abdomen: sternite 5 a little higher than wide; anterior incision almost straight (Figure 10). Terminalia: cercal plate with numerous long setae; surstili long (Figures 11 and 12); phallic complex as in Figures 13 and 14.

Comments: Marques and Couri (2007) extended the distribution of G. tropicalis to Colombia and Brazil and now it is also recorded in Costa Rica. The male is described for the first time. To a full description and drawings of female see Marques and Couri (2007).

Material examined: Costa Rica: Prov. Guanacaste, P. N. Guanacaste, Est. Pitilla, 700 m, 9 km S. Sta. Cecília, 31.iii-29.iv.1992, K. Taylor. L-N- 330200- 380200, 2 females (INBC); Prov. Alaju, R. San Lorencito, 900 m. R. F. San Ramón, 5 km N. de Colonia Palmareña, 13-18. vi.1993, I Curso
Scarabaeidae. L-N-244500- 470700, 1 male (INBC); Prov. Here, Est. Magsasay, P. N. Bráulio Carrillo, 200 m, viii.1990, R. Aguilar. L-N-264600-531100, 1 female (INBC); same locality and collector, i.1991, 3 females (2 INBC; 1MN RJ); Sendero Est. Magsasay a R. Sardinalito, 150-350 m., i.1991, A. Fernandez. L-N- 261500- 531000, 1 female (INBC); Prov. Cart., Ref. Nac. Fauna Silv. Tapanti, 1,250 m. viii.1991, F. A. Quesada. L-N-194000- 559800, 1 female (INBC); Prov. Limon, Est. Hitoy Cerere, 100 m. R. Cerere, Res. Biol. Hitoy Cerere, ix.1991, G. Carballo. L-N-184200-643300, 5 females (INBC); Prov. Puntarenas, Est. Sirena, 100 m. P. N. Corcovado, iv.1992, G. Rodriguez. L-S-270500-508300, 1 female (INBC); Est. Agujas. Cerro Rincón. 600-745 m, 20 - 23.i.1997, M. Lobo. L-S-275500-521950\#45509, 3 males (INBC) e 1 macho (MNRJ); Camino Tablas. Cotoncito, $3.5 \mathrm{~km}$ N. de la Lucha. 1,600m, 9.i.1998, E. Navarro. L-S- 322100- 597200\#48863, 1 macho (MNRJ); Cotoncito, 3.5 km. N. de la Lucha. 1,600 m, 15.xii.1997, A. Picado. L-S- 322100- 597200\#48786, 1 male (INBC); Est. Biológica Lãs Cruces. San Vito Coto Brus. 1,200 m, 23-25.i.1998, M. A. Zumbado. L-S- 304500- 577500\#49971, 1 male (INBC); Buen Amigo, San Luis Monteverde. 1,000-1,350 m, iv.1995, Z. Fuentes. L-N-250850- 449250\#4801, 1 macho (INBC); A. C. Amistad, Buenos Aires, Sector Altamira, 1 km S. O. del Cerro Billey. 1,400 m, x.1994, M. Segura. L-S-331500-571700\#3297, 1 male (INBC); Coto Brus, Est. Biol. Lãs Alturas, 1,500 m, ix.1991, M. Ramirez. L-S-322500-591300, 1 male (INBC); Est. Pitttier, 1,670 m, 23.viii-13.ix.1995, E. Navarro. L-S-330900-577400\#6153, 1 fêmea (INBC); Prov. San Jose, Las Nubles, Santa Elena, Viejo, Est. Santa Elena. 1,210 m, 4-15.i.1996, E. Alfaro, Amarilla. L-S-371750-507800\#6864, 2 females (INBC); Est. Santa Elena, Las Nubles. 1,210 m, 5-19.vii.1996, E. Alfaro, Amarilla. L-S-371750-507800\#7920, 1 female (INBC); Sendero La Bota, Est. Santa Elena, 1,690 m, 25.iv.96, E. Alfaro. L-S-373400-507300\#7344, 1 female (MNRJ).

Acknowledgements - The authors are grateful to Dr. Manuel Zumbado (Instituto Nacional de Biodiversidad, Costa Rica) for the loan of the material and to Mr. Luís Antonio Alves da Costa (Museu Nacional) for the final preparation of the drawings. $\mathrm{MSC}$ is also grateful to $\mathrm{CNPq}$ for the research grant and financial support for her project (process number 300370/2004-0).

\section{References}

ALBUQUERQUE, D. de O., 1954, "Graphomya analis" (Malloch, 1934) nec Macquart, 1850, uma espécie nova (Diptera, Muscidae). Revista Brasileira de Biologia, vol. 14, no. 1, p. $79-82$

CARVALHO, CJB., COURI, MS., PONT, AC., PAMPLONA, D. and LOPES, SM., 2005. A catalogue of the muscidae (Diptera) of the neotropical region. Zootaxa, vol. 860, p. 1-282. 
COURI, MS. and CARVALHO, CJB., 2002. Part II. Apical groups. In CARVALHO, CJB. (Ed.). Muscidae (Diptera) of the neotropical region: taxonomy. Curitiba: Editora da Universidade Federal do Paraná. 287p.

COURI, MS. and MARQUES, B., 2005. A new species of Graphomya Robineau-Desvoidy (Diptera, Muscidae). Revista Brasileira de Zoologia, vol. 22, no. 3, p. 761-763.

GIGLIO-TOS, H., 1893. Diagnosi di nuovi generi e di nuove specie di Ditteri. VIII. Bolletino dei Musei di Zoologia ed
Anatomia Comparata della Regia Universita di Torino, vol. 8, no. $147,11 \mathrm{p}$.

MALLOCH, JR., 1934. Muscidae. Diptera of Patagonia and South Chile, vol. 7, no. 2, p. 171-346.

MARQUES, B. and COURI, MS., 2007. Taxonomia e morfologia das espécies neotropicais de Graphomya Robineau-Desvoidy (Diptera, Muscidae). Revista Brasileira de Entomologia, vol. 51 , no. 4, p. 436-444.

McAlPINE, JF., 1981. Manual of Neartic Diptera. OttawaResearch Branch Agriculture Canada, vol. 1, 674p. 